\title{
Perioperative and postoperative risk factors for corneal graft failure
}

This article was published in the following Dove Press journal:

Clinical Ophthalmology

28 August 2014

Number of times this article has been viewed

\author{
Alice L Yu' \\ Michaela Kaiser' \\ Markus Schaumberger ${ }^{1}$ \\ Elisabeth Messmer' \\ Daniel Kook' \\ Ulrich Welge-Lussen ${ }^{2}$ \\ 'Department of Ophthalmology, \\ Ludwig-Maximilians-University, \\ Munich, ${ }^{2}$ Department of \\ Ophthalmology, Friedrich-Alexander- \\ University, Erlangen, Germany
}

Purpose: In this study, we assessed the outcome of penetrating keratoplasties using organ-cultured corneal tissues at the University Eye Hospital, Ludwig-Maximilians-University, Munich, Germany. The goal was to identify perioperative and postoperative risk factors that may affect graft survival.

Patients and methods: The medical records of 377 patients who underwent a penetrating keratoplasty between 2001 and 2011 were reviewed. Organ-cultured corneal tissue was obtained from the eye bank of Ludwig-Maximilians-University. Perioperative and postoperative risk factors for graft failure were evaluated by univariate and multivariate analyses.

Results: The 5-year overall survival rate of penetrating keratoplasties was $68 \%$. Graft failure occurred in $26 \%$ of patients. High-risk keratoplasties, such as repeat penetrating keratoplasties and emergency penetrating keratoplasties, as well as postoperative conditions, such as glaucoma, retinal surgery, suture problems, persistent epithelial defect, infectious keratitis, and graft rejection, were significantly associated with graft failure in the multivariate analyses.

Conclusion: This study showed a similar graft-survival rate as demonstrated in previous studies. In addition, a number of perioperative and postoperative risk factors were identified in this specific patient population.

Keywords: penetrating keratoplasty, graft failure, risk factor, cornea bank

\section{Introduction}

Corneal transplantations can involve either the transplantation of the full-thickness cornea or the anterior or posterior layers of the cornea. ${ }^{1,2}$ The choice of the technique depends on the preoperative indication. Despite these diverse technical options, penetrating keratoplasty with a full-thickness corneal graft is still the most common procedure. Penetrating keratoplasty can be done as a single procedure or in combination with cataract surgery or pars plana vitrectomy. Besides a primary penetrating keratoplasty, this procedure can also be performed after graft failure or after corneal perforation. Therefore, there are various perioperative factors that may determine the outcome of graft survival.

The postoperative condition is an important factor influencing graft survival. Postoperative complications or interventions determine the survival of a corneal graft. The failure may take place in the immediate postoperative period, but also months or years after corneal transplantation. Therefore, corneal graft failure may occur early or late during the postoperative follow-up period. This failure involves the loss of transparency of the corneal graft and leads to reduction of visual acuity. Postoperative risk factors also include glaucoma or graft rejection. Therefore, the outcome of corneal transplantation differs from patient to patient. This fact emphasizes the importance of evaluating the risk factors for corneal transplantation in each specific setting.
Correspondence: Alice L Yu Department of Ophthalmology, Ludwig-Maximilians-University, 8 Mathildenstrasse, Munich 80336, Germany

Tel +49895I60 38II

$\mathrm{Fax}+498951603051$

Email alice.yu@med.uni-muenchen.de 
In this study, we investigated the risk factors for graft failure in patients undergoing penetrating keratoplasties at the University Eye Hospital, Ludwig-Maximilians-University, Munich, Germany. All patients received organ-cultured donor corneas of the eye bank of the University Eye Hospital. The eye bank was founded in 1999, and generated more than 1,000 corneal transplants between 1999 and 2011. Since 1999, most corneal tissues of the eye bank have been used for penetrating keratoplasties. Until now, there have been no studies analyzing the perioperative and postoperative risk factors for graft failure with organ-cultured corneal tissues of this eye bank. Therefore, we analyzed the outcome of penetrating keratoplasties in terms of long-term graft survival and identified perioperative and postoperative risk factors for graft failure in a specific patient population.

\section{Patients and methods}

In this study, the medical records of 377 patients were analyzed retrospectively. All patients received a penetrating keratoplasty with an organ-cultured corneal tissue at the University Eye Hospital between 2001 and 2011. The follow-up period was at least 1 year. All organ-cultured corneal tissues were acquired from the eye bank of LudwigMaximilians-University. They were recovered by enucleation of the whole eye, stored as a corneoscleral ring in organ culture at $37^{\circ} \mathrm{C}$, and selected for transplantation with a minimal endothelial cell density of 2,000 cells $/ \mathrm{mm}^{2}$. This study was performed in accordance with the ethical standards laid down in the 1964 Declaration of Helsinki and was approved by the local ethics committee. The following data were extracted from the patients' files: patients' demographic data, ocular history including the indication for surgery, perioperative events (surgical procedure, combined operations with cataract surgery, pars plana vitrectomy, anterior-lens exchange/ implantation, size of the donor and recipient cornea, and endothelial cell density), postoperative follow-up status and postoperative complications. These data were obtained for at least three time points: 1 month, 3 months, and 12 months after surgery.

The surgical procedure of the penetrating keratoplasty started with the trephination of the donor cornea. The recipient cornea was trephined with a vacuum trephine (Hessburg-Barron; Barron Precision Instruments, MI, USA). The donor cornea was sutured into the recipient cornea by using 10.0 nylon continuous suture in normal-risk penetrating keratoplasties and 10.0 nylon interrupted sutures in high-risk penetrating keratoplasties. For the postoperative period, topical prednisolone acetate $1 \%$ was applied six times a day and then slowly reduced by one drop per month during the following 6 months. Topical antibiotics were used four times a day until the corneal epithelium was closed. In addition, artificial tears were applied until the corneal sutures were removed after 12 months.

Statistical analyses were conducted with the IBM SPSS 21.0 (IBM, Armonk, NY, USA). Descriptive statistics were applied for the calculation of mean values and standard deviations. Graft failure was the primary end point. Graft failure was defined as an existing graft, which became irreversibly edematous and opaque with an irremediable loss of clarity. For each variable, Cox univariate regression analyses were performed. Variables with a $P$-value $\leq 0.01$ were selected and further tested in Cox multivariate regression analyses with a backward-selection procedure to identify potential risk factors for graft failure. The effect of each variable was quantified by hazard ratio. Pearson linear regression analysis was used to find correlations between variables. Categorical variables were evaluated by $\chi^{2}$ tests and Fisher's exact tests. Graft survival was analyzed by Kaplan-Meier survival function. $P$-values $<0.05$ were regarded as statistically significant.

\section{Results \\ Graft outcomes}

Among the total 377 patients, 228 patients (60.5\%) were male and 149 patients $(39.5 \%)$ were female. The mean patient age was $51.3 \pm 23.5$ years. The overall graft-failure rate was $26.5 \%$ (100 patients) during a mean follow-up period of $39.3 \pm 32.2$ years. Among the 100 patients with graft failure, 23 patients had an early graft failure (defined as graft failure $\leq 6$ months postoperatively), and 77 patients experienced a late graft failure (defined as graft failure $>6$ months postoperatively). Median survival time for all 377 penetrating keratoplasties was 40 months. For keratoplasties with graft failure, mean survival time was 23.4 months. The 1-, 2-, 3-, 4-, 5-, and 10-year survival rates were $87.8 \%, 81.0 \%, 73.6 \%$, $72.5 \%, 68.4 \%$, and 53.3\%, respectively (Figure 1).

The three most common indications for penetrating keratoplasties were keratoconus (26.8\%, 101 patients), infectious keratitis $(12.5 \%, 47$ patients), and preoperative graft failure (11.7\%, 44 patients). Univariate regression analysis demonstrated that most indications for penetrating keratoplasties were significantly associated with graft failure (Table 1). In the multivariate analysis, keratoconus, Fuchs's endothelial dystrophy, corneal stromal dystrophy, bullous keratopathy, and corneal scar of unknown origin were not significant for graft failure (Table 2). 


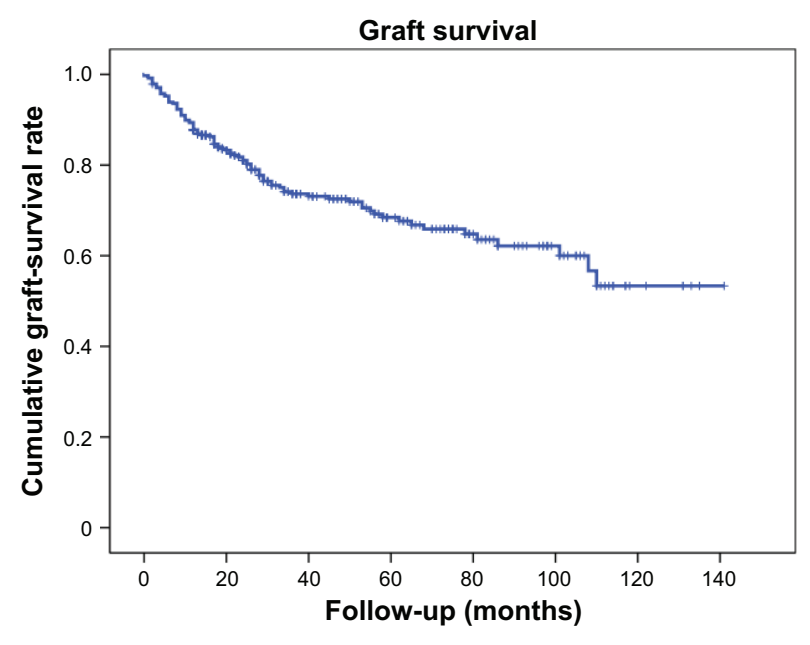

Figure I Graft-survival rate and follow-up period (months).

\section{Perioperative risk factors for graft failure}

Among all penetrating keratoplasties, 300 patients (79.6\%) received a primary keratoplasty, 64 patients $(17.0 \%)$ had a repeat keratoplasty, and 13 patients (3.4\%) an emergency penetrating keratoplasty. Both repeat keratoplasty and emergency penetrating keratoplasty were significantly associated with graft failure. In contrast, combined procedures of penetrating keratoplasty with cataract extraction and posterior-lens implantation (triple procedure), pars plana vitrectomy, or lens exchange/anterior-lens implantation did not significantly influence the graft outcome in terms of graft survival. It became clear that one factor influencing the risk of graft failure is the size of the corneal transplant. The larger the size of the donor cornea, as well as the size of the recipient bed, the higher the risk for graft failure. A high endothelial cell density showed a significantly preventive effect on graft failure. In the multivariate analysis, only repeat penetrating keratoplasty, emergency penetrating keratoplasty, and endothelial cell density were significantly associated with graft failure (Tables 3 and 4).

\section{Postoperative risk factors for graft failure}

The following postoperative risk factors had a significant negative influence on the graft failure: postoperative elevated intraocular pressure, glaucoma medication, cyclophotocoagulation, retinal surgery, surgery of the conjunctiva/cornea, wound leakage, suture problems, persistent epithelial defects, corneal vascularization, infectious or herpetic keratitis, and graft rejection. There was no scoring of the corneal vascularization based on the retrospective study design. Interestingly, cataract operation, laser capsulotomy, sterile keratitis, and anterior synechia had no significant effect on the graft outcome in terms of graft failure. In the multivariate analysis, postoperative glaucoma medication, retinal surgery, suture problems, persistent epithelial defect, infectious keratitis, and graft rejection were shown to be significantly associated with graft failure (Tables 5 and 6).

\section{Discussion}

In this study, the 5-year corneal graft-survival rate for all penetrating keratoplasties was $68 \%$. This rate was comparable to the corneal graft survival of penetrating corneal transplants within the Australian corneal graft registry. ${ }^{3}$ A higher survival rate in various other studies was mostly attributed to a selection bias by including patients with corneal ectasia or keratoconus. ${ }^{4-7}$ These factors are known to be associated with a lower risk of graft failure. ${ }^{8}$ In our

Table I Univariate analyses of indications for penetrating keratoplasties

\begin{tabular}{|c|c|c|c|c|c|}
\hline & \multirow{2}{*}{$\begin{array}{l}\text { Total } \\
n=377(\%)\end{array}$} & \multirow{2}{*}{$\begin{array}{l}\text { Graft failure } \\
n=100(\%)\end{array}$} & \multirow[t]{2}{*}{$\boldsymbol{P}$} & \multicolumn{2}{|c|}{ Univariate analysis } \\
\hline & & & & HR & $95 \% \mathrm{Cl}$ \\
\hline Indication & - & - & $<0.001$ & - & - \\
\hline Keratoconus & I0I (26.8\%) & $2(2.0 \%)$ & Reference & - & - \\
\hline Fuchs's endothelial dystrophy & $37(9.8 \%)$ & $4(4.0 \%)$ & 0.027 & 6.79 & $1.24-37.15$ \\
\hline Infectious keratitis & $47(12.5 \%)$ & $19(19.0 \%)$ & $<0.001$ & 32.46 & $7.53-139.97$ \\
\hline Acute perforation of non-infectious corneal ulceration & $26(6.9 \%)$ & 14 (|4.0\%) & $<0.001$ & 58.42 & $13.17-259.03$ \\
\hline Preoperative graft failure & $44(\mathrm{I} I .7 \%)$ & $21(21.0 \%)$ & $<0.001$ & 35.92 & $8.40-153.53$ \\
\hline Stromal dystrophy of the cornea & $12(3.2 \%)$ & I (I.0\%) & 0.18 & 5.18 & $0.47-57.08$ \\
\hline Bullous keratopathy & $40(10.6 \%)$ & II (II.0\%) & $<0.001$ & 21.83 & 4.83-98.73 \\
\hline Corneal scar of unknown origin & $14(3.7 \%)$ & $3(3.0 \%)$ & 0.009 & 10.92 & $1.82-65.44$ \\
\hline Chemical burn & $9(2.4 \%)$ & $3(3.0 \%)$ & $<0.001$ & 33.78 & $5.60-203.75$ \\
\hline Trauma & $23(6.1 \%)$ & $8(8.0 \%)$ & $<0.001$ & 23.80 & $5.04-112.52$ \\
\hline Glaucoma-associated decompensation & $8(2.1 \%)$ & $7(7.0 \%)$ & $<0.001$ & 82.30 & $16.95-399.53$ \\
\hline Corneal decompensation of unknown origin & $16(4.2 \%)$ & $7(7.0 \%)$ & $<0.001$ & 28.05 & $5.82-135.26$ \\
\hline
\end{tabular}

Abbreviations: $\mathrm{HR}$, hazard ratio; $\mathrm{Cl}$, confidence interval. 
Table 2 Multivariate analyses of indications for penetrating keratoplasties

\begin{tabular}{|c|c|c|c|c|c|}
\hline & \multirow{2}{*}{$\begin{array}{l}\text { Total } \\
n=377 \text { (\%) }\end{array}$} & \multirow{2}{*}{$\begin{array}{l}\text { Graft failure } \\
n=100(\%)\end{array}$} & \multirow[t]{2}{*}{$P$} & \multicolumn{2}{|c|}{ Multivariate analysis } \\
\hline & & & & HR & $95 \% \mathrm{Cl}$ \\
\hline Indication & - & - & $<0.001$ & - & - \\
\hline Keratoconus & I0I (26.8\%) & $2(2.0 \%)$ & Reference & - & - \\
\hline Fuchs's endothelial dystrophy & 37 (9.8\%) & $4(4.0 \%)$ & 0.163 & 3.52 & $0.60-20.64$ \\
\hline Infectious keratitis & 47 (I2.5\%) & $19(19.0 \%)$ & 0.006 & 8.93 & $1.89-42.24$ \\
\hline Noninfectious ulcer & $26(6.9 \%)$ & $14(14.0 \%)$ & $<0.001$ & 32.33 & $6.59-158.76$ \\
\hline Preoperative graft failure & $44(11.7 \%)$ & 21 (2I.0\%) & 0.041 & 5.76 & $1.08-30.79$ \\
\hline Corneal stromal dystrophy & $12(3.2 \%)$ & $\mathrm{I}(\mathrm{l} .0 \%)$ & 0.303 & 3.57 & $0.32-40.36$ \\
\hline Bullous keratopathy & $40(10.6 \%)$ & $\mathrm{II}(\mathrm{II} .0 \%)$ & 0.063 & 4.78 & $0.92-24.81$ \\
\hline Corneal scar of unknown origin & 14 (3.7\%) & $3(3.0 \%)$ & 0.068 & 5.57 & $0.88-35.23$ \\
\hline Chemical burn & $9(2.4 \%)$ & $3(3.0 \%)$ & 0.026 & 9.53 & $1.30-69.77$ \\
\hline Trauma & $23(6.1 \%)$ & $8(8.0 \%)$ & 0.001 & 15.78 & $3.04-81.98$ \\
\hline Glaucoma-associated corneal decompensation & $8(2.1 \%)$ & $7(7.0 \%)$ & 0.006 & 13.76 & $2.13-88.80$ \\
\hline Corneal decompensation of other origin & $16(4.2 \%)$ & $7(7.0 \%)$ & 0.004 & 11.49 & $2.20-59.85$ \\
\hline
\end{tabular}

Abbreviations: $\mathrm{HR}$, hazard ratio; $\mathrm{Cl}$, confidence interval.

study, the preoperative indications included low-risk keratoplasties like keratoconus, moderate-risk keratoplasties such as Fuchs's dystrophy, and also high-risk keratoplasties such as previous graft rejection.

As expected, repeat keratoplasty and emergency penetrating keratoplasty were significantly associated with graft failure in the univariate and multivariate analyses. These results were in accordance with the outcome of repeat penetrating keratoplasties in previous studies. ${ }^{9,10}$ Increased risk of repeat penetrating keratoplasties for graft failure is explained by the increased risk of graft rejection as the host is sensitized. ${ }^{11}$ Since the most common cause of graft failure is graft rejection, ${ }^{12}$ the highest percentage of graft failure in this study was found in patients with regraft. Combined procedures, such as triple keratoplasties, penetrating keratoplasties with pars plana vitrectomy, or anterior-lens exchange/implantation, had no significant influence on the risk of graft failure in our study. These results were in contrast to Fasolo et $\mathrm{al}^{7}$ who showed a 2.8 -fold greater risk of graft failure after penetrating keratoplasty with pars plana vitrectomy. However, Sugar et $\mathrm{al}^{13}$ did not find an increased risk of graft failure after combined operation with vitrectomy in their multivariate analysis either. Whether or not combined keratoplasty is a risk for graft failure remains controversial, since our study only included a rather low number of combined procedures.

In accordance with previous studies, a high endothelial cell density had a protective effect on corneal graft survival, since the endothelial cell loss did not exceed a rate of $2.6 \%-7.8 \%$ per year in the first 3 years postoperatively. ${ }^{14,15}$ On the other hand, a larger size of both the donor cornea and the recipient bed increased the risk for graft failure. This observation may be explained by

Table 3 Univariate analyses of perioperative risk factors

\begin{tabular}{|c|c|c|c|c|c|}
\hline \multirow[t]{2}{*}{ Perioperative variables } & \multirow{2}{*}{$\begin{array}{l}\text { Total } \\
n=377 \text { (\%) }\end{array}$} & \multirow{2}{*}{$\begin{array}{l}\text { Graft failure } \\
n=100(\%)\end{array}$} & \multirow[t]{2}{*}{$\mathbf{P}$} & \multicolumn{2}{|c|}{ Univariate analysis } \\
\hline & & & & HR & $95 \% \mathrm{Cl}$ \\
\hline Surgical procedure & - & - & $<0.001$ & - & - \\
\hline Penetrating keratoplasty & $300(79.6 \%)$ & $63(63.0 \%)$ & Reference & - & - \\
\hline Repeat keratoplasty & $64(17.0 \%)$ & $29(29.0 \%)$ & $<0.001$ & 2.74 & $1.76-4.26$ \\
\hline Emergency keratoplasty & $13(3.4 \%)$ & $8(8.0 \%)$ & $<0.001$ & 6.94 & $3.27-14.72$ \\
\hline Combined procedures & - & - & 0.314 & - & - \\
\hline None & $298(79.0 \%)$ & 75 (75.0\%) & Reference & - & - \\
\hline Triple procedure* & $52(13.8 \%)$ & 14 (14.0\%) & 0.532 & 1.20 & $0.68-2.13$ \\
\hline Pars plana vitrectomy & I5 (4.0\%) & $6(6.0 \%)$ & 0.152 & 1.84 & $0.80-4.22$ \\
\hline Lens exchange/anterior lens implantation & $12(3.2 \%)$ & $5(5.0 \%)$ & 0.207 & 1.79 & $0.72-4.44$ \\
\hline Size of donor cornea $(\mathrm{mm})$ & 7.77 & 7.87 & 0.041 & 1.31 & $1.01-1.70$ \\
\hline Size of recipient cornea $(\mathrm{mm})$ & 7.54 & 7.65 & 0.016 & 1.35 & $1.06-1.7 \mid$ \\
\hline Endothelial cell density (per mm²) & 2,694 & 2,648 & 0.004 & 0.99 & $0.99-1.00$ \\
\hline
\end{tabular}

Notes: *Pars plana vitrectomy, cataract extraction, and lens implantation.

Abbreviations: $\mathrm{HR}$, hazard ratio; $\mathrm{Cl}$, confidence interval. 
Table 4 Multivariate analysis of perioperative risk factors

\begin{tabular}{|c|c|c|c|c|c|}
\hline \multirow[t]{2}{*}{ Perioperative variables } & \multirow{2}{*}{$\begin{array}{l}\text { Total } \\
n=377 \text { (\%) }\end{array}$} & \multirow{2}{*}{$\begin{array}{l}\text { Graft failure } \\
n=100(\%)\end{array}$} & \multirow[t]{2}{*}{$P$} & \multicolumn{2}{|c|}{ Multivariate analysis } \\
\hline & & & & HR & $95 \% \mathrm{Cl}$ \\
\hline Surgical procedure & - & - & $<0.001$ & - & - \\
\hline Penetrating keratoplasty & $300(79.6 \%)$ & $63(63.0 \%)$ & Reference & - & - \\
\hline Repeat keratoplasty & $64(17.0 \%)$ & $29(29.0 \%)$ & $<0.001$ & 2.82 & I.77-4.48 \\
\hline Emergency keratoplasty & $13(3.4 \%)$ & $8(8.0 \%)$ & $<0.001$ & 5.99 & $2.76-13.03$ \\
\hline Endothelial cell density (per mm²) & 2,694 & 2,648 & 0.025 & 0.99 & $0.99-1.00$ \\
\hline
\end{tabular}

Abbreviations: $\mathrm{HR}$, hazard ratio; $\mathrm{Cl}$, confidence interval.

an increased risk of graft rejection in larger donor grafts, since there is a higher number of dendritic Langerhans cells in the limbal region of the cornea than in the central cornea. ${ }^{16,17}$ Furthermore, a larger donor cornea needs to be positioned closer to the limbal region, and is therefore more exposed to the antigen/ antibody influences of the limbal vasculature.

Besides these perioperative risk factors, there were multiple postoperative risk factors that were associated with a higher risk of graft failure. In particular, glaucoma and associated glaucoma medication, retinal surgery, suture problems, persistent epithelial defect, infectious keratitis, and graft rejection were shown to be significant factors for graft failure both in the univariate and multivariate analyses. These results were consistent with previous studies. ${ }^{18-20} \mathrm{An}$ Australian Corneal Graft Registry analysis found that 8.5\% of graft failures occurred in eyes with glaucoma. ${ }^{8}$ The risk for postoperative glaucoma is increased in aphakic eyes, elderly patients, traumatized eyes, and repeat corneal grafts. ${ }^{11}$ The mechanism for this effect is still unknown. ${ }^{11}$ Postoperative interventional procedures, such as postoperative cataract surgery or laser capsulotomy, had no significant effect on graft survival. From previous studies, it is known that cataract

Table 5 Univariate analyses of postoperative risk factors

\begin{tabular}{|c|c|c|c|c|c|}
\hline \multirow[t]{2}{*}{ Postoperative variables } & \multirow{2}{*}{$\begin{array}{l}\text { Total } \\
n=377 \text { (\%) }\end{array}$} & \multirow{2}{*}{$\begin{array}{l}\text { Graft failure } \\
n=100(\%)\end{array}$} & \multirow[t]{2}{*}{$P$} & \multicolumn{2}{|c|}{ Univariate analysis } \\
\hline & & & & HR & $95 \% \mathrm{Cl}$ \\
\hline Elevated intraocular pressure $\geq 2 \mathrm{I} \mathrm{mmHg}(\mathrm{mmHg})$ & 21.90 & 26.08 & $<0.001$ & 1.05 & $1.03-1.07$ \\
\hline Glaucoma medication* & 137 (36.3\%) & $61(61.0 \%)$ & $<0.001$ & 2.85 & $1.90-4.25$ \\
\hline Glaucoma surgery & - & - & 0.079 & - & - \\
\hline None & $356(94.4 \%)$ & $90(90.0 \%)$ & Reference & - & - \\
\hline Trabeculectomy & $2(0.5 \%)$ & $\mathrm{I}(1.0 \%)$ & 0.695 & 1.49 & $0.21-10.67$ \\
\hline Cyclophotocoagulation & $19(5.0 \%)$ & $9(9.0 \%)$ & 0.026 & 2.19 & I.10-4.35 \\
\hline Cataract surgery & $4 \mathrm{I}(10.9 \%)$ & $12(12.0 \%)$ & 0.627 & 0.86 & $0.47-1.58$ \\
\hline Retinal surgery & $25(6.6 \%)$ & $15(15.0 \%)$ & $<0.001$ & 3.16 & I.82-5.48 \\
\hline Surgery of the conjunctiva/cornea & $33(8.8 \%)$ & $20(20.0 \%)$ & $<0.001$ & 3.14 & $1.92-5.14$ \\
\hline Other intraocular surgery & $30(8.0 \%)$ & $\mathrm{II}(\mathrm{II} .0 \%)$ & 0.201 & 1.51 & $0.80-2.82$ \\
\hline Laser capsulotomy & $23(6.1 \%)$ & $5(5.0 \%)$ & 0.208 & 0.56 & $0.23-1.38$ \\
\hline Wound leakage & - & - & $<0.001$ & - & - \\
\hline None & $304(80.6 \%)$ & $66(66.0 \%)$ & Reference & - & - \\
\hline Without intervention & $48(12.7 \%)$ & $21(21.0 \%)$ & $<0.001$ & 2.56 & $1.56-4.19$ \\
\hline With suturing & $25(6.6 \%)$ & $13(13.0 \%)$ & 0.013 & 2.13 & I.17-3.87 \\
\hline Suture problems & $113(30.0 \%)$ & $45(45.0 \%)$ & $<0.001$ & 2.25 & $1.52-3.34$ \\
\hline Persistent epithelial defect ( $\geq 3$ months) & $33(8.8 \%)$ & $24(24.0 \%)$ & $<0.001$ & 4.54 & $2.86-7.20$ \\
\hline Corneal vascularization & $100(26.5 \%)$ & $55(55.0 \%)$ & $<0.001$ & 3.64 & $2.45-5.40$ \\
\hline Keratitis & - & - & $<0.001$ & - & - \\
\hline None & $318(84.4 \%)$ & $64(64.0 \%)$ & Reference & - & - \\
\hline Sterile & $15(4.0 \%)$ & $4(4.0 \%)$ & 0.378 & 1.58 & $0.57-4.33$ \\
\hline Bacterial & $34(9.0 \%)$ & $25(25.0 \%)$ & $<0.001$ & 6.37 & $3.99-10.17$ \\
\hline Herpes simplex virus & $10(2.7 \%)$ & $7(7.0 \%)$ & $<0.001$ & 4.29 & $|.96-9.4|$ \\
\hline Anterior synechia & $60(16.0 \%)$ & $22(22.0 \%)$ & 0.163 & 1.40 & $0.87-2.25$ \\
\hline Graft rejection ${ }^{\dagger}$ & $85(23.8 \%)$ & $47(47 \%)$ & $<0.001$ & 3.48 & $2.35-5.17$ \\
\hline
\end{tabular}

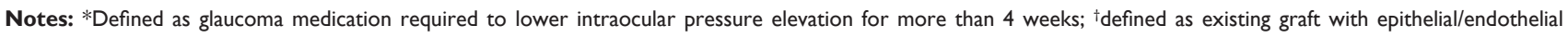
rejection line or anterior-chamber reaction with corneal edema and infiltrates.

Abbreviations: $\mathrm{HR}$, hazard ratio; $\mathrm{Cl}$, confidence interval. 
Table 6 Multivariate analysis of postoperative risk factors

\begin{tabular}{|c|c|c|c|c|c|}
\hline \multirow[t]{2}{*}{ Postoperative variables } & \multirow{2}{*}{$\begin{array}{l}\text { Total } \\
n=377 \text { (\%) }\end{array}$} & \multirow{2}{*}{$\begin{array}{l}\text { Graft failure } \\
n=100(\%)\end{array}$} & \multirow[t]{2}{*}{$P$} & \multicolumn{2}{|c|}{ Multivariate analysis } \\
\hline & & & & HR & $95 \% \mathrm{Cl}$ \\
\hline Elevated intraocular pressure $\geq 2 \mathrm{I} \mathrm{mmHg}(\mathrm{mmHg})$ & 21.90 & 26.08 & 0.401 & - & - \\
\hline Glaucoma medication* & $137(36.3 \%)$ & $61(61.0 \%)$ & $<0.001$ & 2.87 & $1.88-4.37$ \\
\hline Glaucoma surgery & - & - & 0.735 & - & - \\
\hline None & $356(94.4 \%)$ & 90 (90.0\%) & Reference & - & - \\
\hline Cyclophotocoagulation & $19(5.0 \%)$ & $9(9.0 \%)$ & 0.492 & - & - \\
\hline Retinal surgery & $25(6.6 \%)$ & $15(15.0 \%)$ & 0.004 & 2.30 & $1.31-4.02$ \\
\hline Surgery of the conjunctiva/cornea & $33(8.8 \%)$ & $20(20.0 \%)$ & 0.575 & - & - \\
\hline Wound leakage & - & - & 0.238 & - & - \\
\hline None & $304(80.6 \%)$ & $66(66.0 \%)$ & Reference & - & - \\
\hline Without intervention & $48(12.7 \%)$ & $21(21.0 \%)$ & 0.118 & - & - \\
\hline With suturing & $25(6.6 \%)$ & $13(13.0 \%)$ & 0.729 & - & - \\
\hline Suture problems & $113(30.0 \%)$ & $45(45.0 \%)$ & 0.004 & 1.85 & $1.22-2.82$ \\
\hline Persistent epithelial defect ( $\geq 3$ months) & $33(8.8 \%)$ & $24(24.0 \%)$ & 0.009 & 2.13 & $1.21-3.74$ \\
\hline Corneal vascularization & $100(26.5 \%)$ & $55(55.0 \%)$ & 0.186 & - & - \\
\hline Keratitis/ulcer & - & - & $<0.001$ & - & - \\
\hline None & $318(84.4 \%)$ & $64(64.0 \%)$ & Reference & - & - \\
\hline Bacterial & $34(9.0 \%)$ & $25(25.0 \%)$ & $<0.001$ & 3.49 & $2.05-5.95$ \\
\hline Herpes simplex virus & $10(2.7 \%)$ & $7(7.0 \%)$ & 0.502 & 1.34 & $0.57-3.15$ \\
\hline Graft rejection ${ }^{\dagger}$ & $85(23.8 \%)$ & $47(47 \%)$ & $<0.001$ & 2.65 & $1.77-3.98$ \\
\hline
\end{tabular}

Notes: *Defined as glaucoma medication required to lower intraocular pressure elevation for more than 4 weeks; ${ }^{\dagger}$ defined as existing graft with epithelial/endothelial rejection line or anterior-chamber reaction with corneal edema and infiltrates.

Abbreviations: $\mathrm{HR}$, hazard ratio; $\mathrm{Cl}$, confidence interval.

surgery following penetrating keratoplasty is a safe procedure with a low risk of graft failure. ${ }^{21}$

There are several limitations to our study, which need to be taken into account. First of all, our study design was based on a retrospective review of medical records. Therefore, the quality of data was certainly in part dependent on the documentation provided by the patient files. For our study analyses, we only included clear information from the medical records in regard to graft failure. If a note remained unclear, a second reviewer was consulted. Besides that, the patients of this study belonged to a diverse patient population with a vast number of different indications based on our university setting. This patient population may not reflect the usual patient population for penetrating keratoplasties in most clinics. Furthermore, due to the great number of risk factors, we did not document the time course or nature of the risk factors in detail. This would have helped in earlier detection and treatment of graft failure. ${ }^{22}$ Lastly, a selection bias could not be ruled out, given that new lamellar transplantation techniques were just introduced at the end of the study period. However, none of these patients had a follow-up period of at least 1 year and were therefore excluded.

In summary, we were able to identify a number of perioperative and postoperative risk factors for corneal graft failure with organ-cultured corneal tissues in our study population at the
University Eye Hospital, Munich, Germany. This retrospective review was extracted from the medical records of a $>10$-year study period since the foundation of our university eye bank in 1999. Since the outcome of corneal transplantation differs from patient to patient, it is even more important to outline the factors that may influence graft survival or lead to graft failure in a specific setting, such as in a university hospital.

\section{Acknowledgment}

The data in this study are part of the medical thesis of Michaela Kaiser at the Medical School of LudwigMaximilians-University, Munich, Germany.

\section{Disclosure}

The authors report no conflicts of interest in this work.

\section{References}

1. Dapena I, Ham L, Melles GR. Endothelial keratoplasty: DSEK/ DSAEK or DMEK - the thinner the better? Curr Opin Ophthalmol. 2009;20:299-307.

2. Melles GR, Wijdh RH, Nieuwendaal CP. A technique to excise the Descemet membrane from a recipient cornea (descemetorhexis). Cornea. 2004;23:286-288.

3. Williams KA, Lowe M, Bartlett C, Kelly TL, Coster DJ. Risk factors for human corneal graft failure within the Australian corneal graft registry. Transplantation. 2008;86:1720-1724.

4. Beckingsale P, Mavrikakis I, Al-Yousuf N, Mavrikakis E, Daya SM. Penetrating keratoplasty: outcomes from a corneal unit compared to national data. Br J Ophthalmol. 2006;90:728-731. 
5. Rahman I, Carley F, Hillarby C, Brahma A, Tullo AB. Penetrating keratoplasty: indications, outcomes, and complications. Eye (Lond). 2009;23: 1288-1294.

6. Wagoner MD, Gonnah ES, Al-Towerki AE. Outcome of primary adult optical penetrating keratoplasty with imported donor corneas. Int $\mathrm{Oph}$ thalmol. 2010;30:127-136.

7. Fasolo A, Capuzzo C, Fornea M, et al. Risk factors for graft failure after penetrating keratoplasty: 5-year follow-up from the corneal transplant epidemiological study. Cornea. 2011;30:1328-1335.

8. Williams KA, Esterman AJ, Bartlett C, Holland H, Hornsby NB, Coster DJ. How effective is penetrating corneal transplantation? Factors influencing long-term outcome in multivariate analysis. Transplantation. 2006;81:896-901.

9. Weisbrod DJ, Sit M, Naor J, Slomovic AR. Outcomes of repeat penetrating keratoplasty and risk factors for graft failure. Cornea. 2003;22: 429-434.

10. Al-Mezaine H, Wagoner MD. Repeat penetrating keratoplasty: indications, graft survival, and visual outcome. Br J Ophthalmol. 2006;90: 324-327.

11. Chan CM, Wong TY, Yeong SM, Lim TH, Tan DT. Penetrating keratoplasty in the Singapore National Eye Centre and donor cornea acquisition in the Singapore Eye Bank. Ann Acad Med Singapore. 1997; 26:395-400

12. Patel SV, Hodge DO, Bourne WM. Corneal endothelium and postoperative outcomes 15 years after penetrating keratoplasty. Am J Ophthalmol. 2005;139:311-319.
13. Sugar A, Tanner JP, Dontchev M, et al. Recipient risk factors for graft failure in the cornea donor study. Ophthalmology. 2009;116: 1023-1028.

14. Zacks CM, Abbott RL, Fine M. Long-term changes in endothelium after keratoplasty. A follow-up study. Cornea. 1990;9:92-97.

15. Bourne WM, Hodge DO, Nelson LR. Corneal endothelium five years after transplantation. Ophthalmology. 1994;118:186-196.

16. [No authors listed]. The Australian Corneal Graft Registry: 1990 to 1992 report. Aust N Z J Ophthalmol. 1993;21:1-48.

17. Tuft SJ, Gregory WM, Davison CR. Bilateral penetrating keratoplasty for keratoconus. Ophthalmology. 1995;102:462-468.

18. Muraine M, Sanchez C, Watt L, Retout A, Brasseur G. Long-term results of penetrating keratoplasty. A 10-year-plus retrospective study. Graefes Arch Clin Exp Ophthalmol. 2003;241:571-576.

19. Vajpayee RB, Sharma N, Sinha R, Agarwal T, Singhvi A. Infectious keratitis following keratoplasty. Surv Ophthalmol. 2007;52:1-12.

20. Perera C, Jhanji V, Lamoureux E, Pollock G, Favilla I, Vajpayee RB. Clinical presentation, risk factors and treatment outcomes of first allograft rejection after penetrating keratoplasty in early and late postoperative period. Eye (Lond). 2012;26:711-717.

21. Nagra PK, Rapuano CJ, Laibson PL, Kunimoto DY, Kay M, Cohen EJ. Cataract extraction following penetrating keratoplasty. Cornea. 2004; 23:377-379.

22. Thompson RW Jr, Price MO, Bowers PJ, Price FW Jr. Long-term graft survival after penetrating keratoplasty. Ophthalmology. 2003; 110:1396-1402.
Clinical Ophthalmology

\section{Publish your work in this journal}

Clinical Ophthalmology is an international, peer-reviewed journal covering all subspecialties within ophthalmology. Key topics include: Optometry; Visual science; Pharmacology and drug therapy in eye diseases; Basic Sciences; Primary and Secondary eye care; Patient Safety and Quality of Care Improvements. This journal is indexed on

\section{Dovepress}

PubMed Central and CAS, and is the official journal of The Society of Clinical Ophthalmology (SCO). The manuscript management system is completely online and includes a very quick and fair peer-review system, which is all easy to use. Visit http://www.dovepress.com/ testimonials.php to read real quotes from published authors. 